\title{
An Investigation and Analysis on the Current Situation of College Students' Recognition on Socialist Core Values*
}

\author{
Zhaohui Du \\ Tianjin Agricultural University \\ Tianjin, China 300384
}

\author{
Jing Dong \\ Tianjin Agricultural University \\ Tianjin, China 300384
}

\begin{abstract}
This study mainly investigates the current state of college students' identification on socialist core values, analyzes the existing problems, and forms a feasible training strategy. The results of the study show that the major existing problems are that college students have poor recognition on socialist core value, lack confidence in the development goals of the country and society, and put emphasis on the theory of socialist core values rather than social practice. Through the analysis of specific reasons, the following countermeasures are put forward: we will perfect the institutional mechanism that colleges and universities cultivate college students' socialist core values, strengthen the network ideological and political education for students, pay special attention to the battle position of ideological and political education, take the college students' actual needs as the main subject, innovate the methods of education, and regard the characteristics of contemporary college students as the starting point to stimulate their learning motivation.
\end{abstract}

Keywords—college students; socialist core values; recognition

\section{INTRODUCTION}

The Sixth Plenary Session of the 17th CPC Central Committee has made it clear that "the socialist core value system is the soul of revitalizing the country and must be integrated into the whole process of national education", and "we must effectively transfer the socialist core value system into people's conscious pursuit". The 18th CPC Central Committee has concluded the most essential content of the socialist core value system, pointed out the basic category of the socialist core values, first put forward the "three advocacies", and formed a 24-word policy of socialist core values. At present, China's colleges and universities conduct the socialist core value system education on college students, and its central task is to make college students highly recognize and consciously practice the socialist core values.

Combined with the background of current socialist core value recognition, this study takes some of the college students in Tianjin as an example, makes an empirical analysis on the both sides of current situation of college students' socialist core value recognition proceeding from the practical significance, grasps the development situation of college

*Fund program: 1. 2016 Tianjin Education System Research Topic. 2. 2016 Science and Technology Development Fund Project of Tianjin Agricultural University (2016SZZX01). students' socialist core value recognition, deeply discusses the cultivation policies of college students' socialist core value recognition, and broadens the cultivation path for college students to practice the socialist core values, so as to further promote the construction of the national socialist core value system and provide value motivation to achieve the Chinese dream and great rejuvenation of Chinese nation.

\section{RESEARCH METHOD}

This study adopts a quantitative questionnaire survey, which is mainly conducted among freshmen, sophomores, juniors and seniors majoring in liberal arts, science and engineering and agricultural science. A total of 440 questionnaires were distributed and 421 questionnaires were collected. The survey sites include Tianjin Agricultural University, Tianjin University of Technology, Tianjin Chengjian University and Tianjin Polytechnic University. Among the surveyed students, divided by grade, 71 students are freshmen, 192 are sophomores, 122 are juniors, and 36 are seniors; divided by gender, there are 144 boys and 277 girls; Divided by major, 82 belong to agricultural science majors, accounting for $19 \%$ of the total, and 231 major in science and engineering, accounting for $55 \%$ of the total, and 108 belong to humanities \& social science majors, accounting for $26 \%$ of the total; divided by whether they are the student cadres, 178 are student cadres, accounting for $42 \%$ of the total, and the rest are ordinary students; divided by politics status, 55 are members of Communist Party of China, accounting for $13 \%$ of the total, and 366 are members of the Communist Youth League or the masses, accounting for $87 \%$ of the total.

The core of the questionnaire design defines the socialist core value as three dimensions, namely, country, society and individual. It is respectively divided into four major content in the three dimensions, of which the national dimension includes prosperity, democracy, civilization and harmony, and the social dimension includes freedom, equality, justice and the rule of law, and the individual dimension includes patriotism, dedication, integrity and friendliness.

On data analysis, we mainly use Excel data analysis software of the computer to obtain the final results through data statistics, quantity transformation, chart analysis and so on 


\section{The Major Problems in College Students' RECOGNITION ON SOCIALIST CORE VALUES}

\section{A. College Students Have Poor Awareness of Socialist Core Values}

The premise of identifying with the socialist core values is that the college students have enough awareness of it. Through investigation, $62 \%$ of college students have a complete understanding on the socialist core values, but nearly $40 \%$ of college students can still not fully understand the conciseness of 24-word policy, the socialist core values, and mistake the 8 words at a certain level as the complete content of the socialist core values. It shows that this part of students has not formed the complete concept about the 24 words of socialist core values and they are not clear about the connotation and significance of the socialist core values. Without complete cognition, there will be no substantive identification, or there will be identification deviations in some aspects. Therefore, we must attach great importance to the propaganda and education of socialist core values.

\section{B. Lack Confidence in the Development Goals of the Country and Society}

As shown in the survey, some college students lack sufficient confidence in the value goal of country and society. Nearly $32 \%$ of students lack confidence in whether the socialist road with Chinese characteristics can make our country prosperous, democratic, civilized and harmonious, which reflects that they not only lack confidence in the socialist road with Chinese characteristics under the leadership of the Chinese Communist Party, but also in the value goal at the national level. If college students are not firm in the socialist road with Chinese characteristics, they will be vulnerable to the influence of western hostile forces, and stuck in the conflict and confrontation with the development of our socialist cause. On the issue of China's democratic mode, $18 \%$ of college students are influenced by the western cultural thoughts unconsciously, and then choose the democracy of Northern Europe and US and Britain as a template. Similarly, on the issue of equality of all people, $13 \%$ of college students believe that it is impossible to achieve equality between people, and $15 \%$ of students think that the equality of all people is too idealistic, as long as they can enjoy equality, which reflects that they lack confidence in the goal of achieving universal equality at the social level, and do not believe our modern socialist countries can achieve equality for all citizens.

\section{Emphasize Theoretical Identification Rather than Individual Practice}

The results of the survey show that most college students can identify with the socialist core values, and $87 \%$ of college students believe that the socialist core values are closely related to everyone, and we not only need to advocate it but also to fulfill it. However, it only embodies in theoretical identification, and a deviation between personal value, behavioral practice and theoretical identification actually exists. For example, they do not have deep patriotic sentiments. $39 \%$ of college students have patriotic feelings when some special events occur. Their professional dedication is not good enough.
In the absence of overtime pay, $41 \%$ of college students sometimes sacrifice their spare time to complete their work, and $10 \%$ of them will not. Without the constraints of the ethical code, they have weak sense of integrity. During the exam, in the case of finding others cheating, up to $66 \%$ of the college students will not stop them and turn a blind eye, and $8 \%$ of college students find others cheating and they themselves also cheat. From the above investigation and analysis, it can be seen that the college students identify with the socialist core values theoretically, and they do not fit in with the socialist core values in terms of individual values and practical behaviors. This shows that the socialist core values have not been truly internalized and become their values and value criterion, and will not be externalized as their behavior practices.

\section{AnAlysis of the CAUSE OF COLlege Students' RECOGNITION ON SOCIALIST CORE VALUES}

\section{A. The Impact of Imbalances in the Development of Modern Society}

Since reform and opening up, China's economy has developed rapidly, and citizens' living standards have generally improved. But at the same time, The gap between the rich and the poor appears, and the economic development in urban and rural areas is unbalanced, and there is a big gap in education levels due to the unbalanced educational resources between urban and rural areas, and there are even some unhealthy social phenomena such as official corruption, "money and right make light work", and inequality of citizenship in certain period. The group of college students has just grown up in this stage of social development. The imbalances that occur will affect their ideals, beliefs and patriotism, and they will lack information in the goals of the development of country and society, and even have a rejection when they accept socialist core values.

\section{B. The Induction of Misconceptions on the Information Network Platform}

In today's society with rapid development of information, the Internet has become an indispensable part of our lives, as well as a main channel for us to obtain all information. A lot of information will impact our attention and thinking every day. However, in the absence of perfect network supervision, there will be many negative information and various erroneous ideas In order to increase the public attention, some online media exaggerate some information and even distort the truth, misleading people. College students are a group that is very interested in new things, as well as a mainstream group in using the Internet. However, they have not fully stepped into the society, cannot clearly see the essence of some bad phenomena in the society and make a clear distinction between right and wrong, and are easily induced by all kinds of wrong ideas on the network to form the wrong values. At the same time, when they are influenced by a variety of ideas, they will be confused and lose their goals. Moreover, some hostile forces also make bad online public opinion to corrupt our minds by using network positions, especially the young college students. 


\section{The Unsound Educational Mechanism of Colleges and Universities in the Education of Socialist Core Values}

Colleges and universities undertake the main task to educate college students about socialist core values. They should generally design the program for the education of the socialist core values of college students, supervise its implementation, and establish the institutional mechanisms and guarantees. In reality, some universities do not pay attention to this, and lack a sound education mechanism and guarantee. The result is that the teachers of ideological and political theory do not focus on the core values of socialism in the classroom, or simply narrates some concepts in a perfunctory manner. Some college students' ideological and political education workers including league secretary and counselors lack socialist core value education in the students' extracurricular activities and daily works. The regulators do not make design and attach importance and the citizens do not implement it. Therefore, some college students will have a low awareness of socialist core values, cannot internalize the values in their minds and externalize it in their behaviors, making the socialist core values only a slogan that colleges often call.

\section{Teachers and Workers of Ideological and Political Education Lack Innovativeness}

Ideological and political theory teachers play an important role in theoretical explanation in the process of the education of college students' socialist core values. They need to arouse the students' attention and understanding on socialist core values in the first class, which will enable the students to have cognition of the socialist core values. The teaching methods of some teachers are obsolete, monotonous and boring. They will teach the students with the content that are written in the textbook, lack of innovativeness and have not given full consideration to students. Students begin to study political theory classes from junior high school, while in college, it is still the same knowledge and the same way of teaching method, which makes students feel bored and indifferent to the teaching of knowledge.

The ideological and political education workers play an important role in practical experience in the process of the education of college students' socialist core values. They need to conduct the theme education activities of socialist core values in the second classroom, and increase the sense of identity of the socialist core values and the consciousness of practicing the socialist core values through firsthand experience and practice. However, the second classroom education of the socialist core values is still preached through the meeting, which stays in the theoretical propaganda, is not innovative and cannot be well connected with the current college students' learning and life. The result of the survey on the connection degree between socialist core values and daily learning and living shows that $47 \%$ of college students believe that the socialist core values are related to daily learning and life, but not much, and $12 \%$ of college students believe that there is no connection.

\section{Cultivation Policy OF COLlege Students SOCIALIST CORE VALUES}

\section{A. Perfect the Institutional Mechanism that Colleges and Universities Cultivate College Students' Socialist Core Values}

A sound institutional mechanism is the guiding direction and effective guarantee for cultivating the socialist core values of college students. In light of universities' actual conditions and characteristics, Party committees of colleges and universities should formulate a scientific training program for the socialist core values of college students, assign the main educational tasks of the ideological and political theory class teachers and ideological and political workers, and establish a performance evaluation system and guarantee mechanism for the education of socialist core values. Meanwhile, we must create good campus education environment through good campus culture construction. Strengthening the construction of campus culture is to create a healthy, lively and orderly cultural atmosphere through scientific management, perfect system and healthy collective activities, so as to fully embody the characteristics of the times of campus culture[1].

\section{B. Strengthen Network Ideological and Political Education and Grasp the Main Position of Network Ideological and Political Education}

Through the survey, most students believe that the Internet has a greater influence on college students' socialist core values than universities. Therefore, the network should become the main position for us to carry out the education of socialist core values for college students in the future, as well as a challenging position. First, we will publicize and carry forward the socialist core values through the network platform. We will set up a section with a theme of socialist core values education on the university's website, secondary school's website and university's official micro-blog, push the theme content of socialist core values education by using QQ, WeChat and other media, and vigorously publicize and carry forward the socialist core values through pictures, micromovies, video, animation, text and other forms that students are interested in. Second, we will grasp the Internet public opinion and provide a correct guidance. University teachers must be good at collecting and analyzing student social hot issues, emergencies and doubtful problems that students pay attention to on the Internet, grasp the direction of information dissemination, identify websites that need attention, promptly correct bad thoughts and negative emotions, and formulate effective measures to prevent the expansion of influence. Third, we will use the online platform to counsel students. The current college students prefer to update their ideological dynamics on the Internet. Teachers should be able to promptly pay attention to students with ideological anomalies, provide advice and counseling, and timely solve the ideological and psychological problems that students meet through interaction on the Internet platform. 


\section{Regard College Students' Practical Needs as Main Subject and Innovate Educational Methods}

In order to conduct the education of socialist core values, we will regard students as the main subject of education, take students' actual needs as the starting point, closely connect with the students' daily study and life, innovate the educational methods and enhance the students' active learning interest. Teachers of ideological and political theory course must change the traditional tedious "inculcation" education mode, and closely combine the learning foundation, thinking habit and psychological characteristics of college students at different levels. Based on the overall orientation and goal requirements of "ideological enlightenment, political guidance, and setting high moral values and cultivating person" in ideological and political theory course, it will promote the reform of the teaching mode that is mainly characterized by projectization, specialization, and networking, and is adjusted based on courses [2]. The ideological and political education workers try to use the innovative methods of activity experience and implicit education on the basis of the actual needs and characteristics of students, and make full use of the second classroom to organize a series of socialist core value theme activities to make students actively participate in it, produce physical and mental experience, form emotional experience, and promote cognitive change. Implicit ideological and political education refers to that hide content of education in a certain activity and the surrounding environment, and the educated do not directly feel that they are receiving education in this area, but the activities, and additions and accompaniment around the activity convey this information. For example, we can organize students to visit revolutionary activity memorial site, memorial hall, martyrs cemetery and exhibition hall for the education of socialist core values.

\section{Take the Characteristics of Current College Students as a Starting Point to Stimulate Learning Motivation}

On the basis of the methods of ideological and political education psychology, if we want to enhance college students' recognition and identification on the socialist core values, we must inspire them to learn and accept the socialist core values to make them form motivation. First, we will take the college students' psychological needs as the starting point to stimulate their learning motivation. For example, college students are more concerned about national affairs and have higher enthusiasm for political participation. Based on this characteristic, we can arrange lectures on social hot issues, so as to enable the students to understand party's route, guideline and policy and political views in lectures with strong knowledge and information, to cultivate patriotic their feelings, and to strengthen the education of socialist core values. Second, we will make use of certain incentives to activate college students' existing learning motivation, and make them be good at seizing the social opportunities and using various commemorative days and major social events for the education of socialist core values. For example, we can conduct the patriotism education that do not forget national humiliation by using National Day, "918" and other commemoration days, and make use of rewards and punishments to activate learning motivation. For example, we can conduct debates, speech contests, and essay contests on the theme of socialist core values education, and reward students with good performance, to stimulate their learning needs and enthusiasm in participation.

\section{CONCLUSION}

College students are the successor to the socialist cause, and are the future of the motherland and the hope of the nation. To educate college students on socialist core values is conducive to guiding and stimulating the development direction of the values of the entire society. Due to the impact of imbalances in the development of modern society, and the induction of misconceptions on the information network platform so on, the problems of college students having poor awareness of socialist core values, of emphasizing theoretical identification rather than individual practice are appear. The key to improving college students' recognition of socialist core values is that college teachers guiding and educating them. Colleges and universities establish the institutional mechanism of cultivating college students' socialist core values, implement the program one level by one level, and innovative education methods, socialist core values will gradually be recognized by college students.

\section{REFERENCES}

[1] Huang Li, Zou Shiheng. Survey and Analysis on Acknowledgement of Socialism Core Value in University Students [J]. Journal of Southwest Jiaotong University (JCR Social Science Edition), 2010, 11(3). 黄莉, 邹 世亭. 大学生对社会主义核心价值观的认同调查分析 $[\mathrm{J}]$. 西南交通 大学学报 (社会科学版) ,2010,11(3).

[2] Yu Yongjun, Wang Li. Current Situation of College Students' Recognition on Socialist Core Values and the Cultivation Path [J]. Education and Vocation, 2015(36). 喻永均, 王莉. 大学生对社会主义 核心价值观的认同现状及培育路径 [J]. 教育与职业,2015(36). 